\title{
Corrosion Behavior under Black Deposit on Low Cr Bearing Steels in $\mathrm{NaCl}$ Completion Fluid
}

\author{
Hideki TAKABE, ${ }^{1)}$ Masakatsu UEDA ${ }^{21}$ and Shinji FUJIMOTO ${ }^{31}$ \\ 1) Corporate Research \& Development Laboratories, Sumitomo Metal Industries, Ltd., 1-8 Fuso-cho, Amagasaki $660-0891$ \\ Japan. $\quad$ 2) Sumitomo Metal Industries, Ltd., 1850 Minato, Wakayama 640-8555 Japan. \\ 3) Division of Material and Manufacturing Science, Graduated School of Engineering, Osaka University, 2-1 Yamada-oka, Suita, \\ Osaka 565-0871 Japan.
}

(Received on April 7, 2008; accepted on September 8, 2008)

\begin{abstract}
$3 \% \mathrm{Cr}$ steel has been developed as a tubing material for $\mathrm{CO}_{2}$ oil well considering $\mathrm{CO}_{2}$ corrosion resistance. However, an oil leakage problem occurred 6 months after the start of oil production in a $\mathrm{CO}_{2}$ oil well which was completed by tubing of $3 \% \mathrm{Cr}$ steel. $3 \% \mathrm{Cr}$ steel was exposed to an alkaline $\mathrm{NaCl}$ completion fluid environment before exposed to the oil production environment. Corrosion under the black deposit, which developed locally on $3 \% \mathrm{Cr}$ steel in the $\mathrm{NaCl}$ completion fluid, was identified to be a cause of oil leakage. The conditions of the black deposit formation on $1 \% \mathrm{Cr}$ and $3 \% \mathrm{Cr}$ steels were investigated by immersion test in a simulated $\mathrm{NaCl}$ completion fluid varying dissolved oxygen (DO) concentration, $\mathrm{pH}$ and temperature. $1 \% \mathrm{Cr}$ steel is a representative $\mathrm{Cr}$ bearing steel and used as a comparable material. If the fluid was alkaline and DO concentration was above $77 \mathrm{ppb}$, the black deposit formed locally on $1 \% \mathrm{Cr}$ and $3 \% \mathrm{Cr}$ steels. Localized corrosion was observed just under the black deposit. If the DO concentration was equal to or less than $33 \mathrm{ppb}$, the black deposit did not form. Corrosion behavior of the specimens with the black deposit was also investigated in a simulated oil production environment. It is concluded that corrosion progress under the black deposit on $3 \% \mathrm{Cr}$ steel in the production environment resulted in the oil leakage 6 months after the start of production. The black deposit was identified as $\mathrm{Fe}_{3} \mathrm{O}_{4}$ mainly by X-ray diffraction analysis. In order to prevent oil leakage on $3 \% \mathrm{Cr}$ steels in the oil production environment, it is necessary to control the DO concentration in the alkaline $\mathrm{NaCl}$ completion fluid to or below $33 \mathrm{ppb}$ that prevents formation of the black deposit.
\end{abstract}

KEY WORDS: Cr bearing steel; $3 \% \mathrm{Cr}$ steel; $1 \% \mathrm{Cr}$ steel; $\mathrm{NaCl}$; completion fluid; $\mathrm{Fe}_{3} \mathrm{O}_{4}$; corrosion.

\section{Introduction}

$\mathrm{CO}_{2}$ corrosion is one of the serious problems in the oil and gas industries. Therefore, $3 \% \mathrm{Cr}$ steel has been developed as a tubing material with approximately 4 times longer lifetime than carbon steels in the $\mathrm{CO}_{2}$ environments ${ }^{1-4)}$ and was employed as the tubing material for two $\mathrm{CO}_{2}$ oil wells in Statfjord field at the North sea. However, oil leakage occurred for the one well due to localized corrosion at a seal portion of threaded joint 6 months after the start of oil production. For the other well, no leakage occurred and oil production has been continued. The difference between the two wells was the exposure time to alkaline $\mathrm{NaCl}$ completion fluid. There are two stages for oil well construction. The first is a drilling stage where a borehole is drilled and steel tubings and casings are installed. The second is a completion stage where a completion fluid, which is high-density mixed brine solution, is poured into the inside of the tubing and the annular space between tubing and casing to keep oil from invading and to clean the inside of the tubing which is dirtied by mud during drilling. The tubings are normally exposed to the completion fluid for 7 to $10 \mathrm{~d}$. In the case of the well of oil leakage, the tub- ing of $3 \% \mathrm{Cr}$ steel was exposed to $\mathrm{NaCl}$ completion fluid for about $30 \mathrm{~d}$. In the case of the well without oil leakage, the exposure period was $10 \mathrm{~d}$. The completion fluid used for the both wells was a mixture of high-density $\mathrm{NaCl}$ brine, biocide and oxygen scavenger. The previous investigation using 3\% Cr steel indicated that a black deposit was formed locally on $3 \% \mathrm{Cr}$ steel in the $\mathrm{NaCl}$ completion fluid with $\mathrm{pH}$ more than 11. ${ }^{5}$ Under the black deposit formed on $3 \% \mathrm{Cr}$ steel, localized corrosion progressed extremely which might extend as leakage. However, it was not clear the relationship among DO concentration, $\mathrm{pH}$ and temperature for the formation of the black deposit. Moreover, it was not clear the corrosion mechanism under the black deposit and the process to reach the leakage not immediately after the production start-up but 6 months after.

In this study, immersion tests of $3 \% \mathrm{Cr}$ steel were carried out in $\mathrm{NaCl}$ solution varying $\mathrm{DO}$ concentration, $\mathrm{pH}$ and temperature to investigate the $\mathrm{NaCl}$ completion fluid conditions under which the black deposit formed locally. Electrochemical tests were also conducted to examine corrosion behavior of the steels in $\mathrm{NaCl}$ completion fluids. In addition, immersion test in a simulated oil production environment was carried out using crevice specimens in order to 
investigate corrosion progress under the black deposit. 1\% $\mathrm{Cr}$ steel was also used as comparable material. Based on the test results, the corrosion mechanism under the black deposit and elimination method for the black deposit are proposed.

\section{Test Procedures}

\subsection{Materials and Test Specimens}

The materials examined were $1 \% \mathrm{Cr}$ and $3 \% \mathrm{Cr}$ steels. $1 \% \mathrm{Cr}$ steel is a representative oil country tubular goods (OCTG) and used as a comparable material. The chemical compositions of the test materials are shown in Table $\mathbf{1 .}$

The materials were cut from pipes that were hot rolled, quenched and tempered in a mill. The yield strengths ranged between 550 to $654 \mathrm{MPa}$.

Coupon specimens and crevice test specimens were used for corrosion tests in simulated $\mathrm{NaCl}$ completion fluids and oil production environments. The size of coupon specimen was $30 \mathrm{~mm}$ width $\times 40 \mathrm{~mm}$ length $\times 3 \mathrm{~mm}$ thickness. The crevice test specimen set was a couple of the larger coupon of $30 \mathrm{~mm}$ width $\times 30 \mathrm{~mm}$ length $\times 3 \mathrm{~mm}$ thickness, and the smaller coupon of $15 \mathrm{~mm}$ width $\times 30 \mathrm{~mm}$ length $\times 3 \mathrm{~mm}$ thickness with holes of $5 \mathrm{~mm}$ diameter for fastening together using a bolt and nuts. Electrochemical tests for $1 \%$ $\mathrm{Cr}$ and $3 \% \mathrm{Cr}$ steels were also conducted to measure corrosion potential and anodic polarization curve. The specimen size for the electrochemical test was $15 \mathrm{~mm}$ width $\times 15 \mathrm{~mm}$ length $\times 2 \mathrm{~mm}$ thickness. The side and back of the specimen were covered with silicon gel and the exposed tested area was approximately $1 \mathrm{~cm}^{2}$. All the test specimens were polished with the silicon carbide \#600, and then degreased and rinsed with dichloromethane and methanol.

\subsection{Corrosion Test}

\subsubsection{Corrosion Tests in Simulated $\mathrm{NaCl}$ Completion} Fluid Environments

Crevice test specimens were immersed in the different simulated $\mathrm{NaCl}$ completion fluid by using glass vessel.

The $\mathrm{NaCl}$ completion fluid used for the well of oil leakage consisted of 1.03 specific gravity (SG) NaCl (3.75 wt\% $\mathrm{NaCl}$ ), biocide and oxygen scavenger, and its $\mathrm{pH}$ was adjusted at approximately more than 11 by sodium hydroxide, as shown in Table 2.

However, in this study, $1.03 \mathrm{SG} \mathrm{NaCl}$ solution was used as test solution to simplify experiment. Table 3 shows the test conditions. In order to investigate the condition of black deposit formation, DO concentration and $\mathrm{pH}$ in the $1.03 \mathrm{SG} \mathrm{NaCl}$ solution were changed. The $\mathrm{NaCl}$ solutions with different $\mathrm{DO}$ concentration and $\mathrm{pH}$ are referred as simulated $\mathrm{NaCl}$ completion fluids in this paper.

The following methods were used for changing DO concentration: (a) deaerated test solution with $\mathrm{N}_{2}$ purging, (b) deaerated test solution by adding oxygen scavenger and (c) aerated test solution.

The following methods were applied for changing $\mathrm{pH}$ in test solution: (a) No adjusted ( $\mathrm{pH}=5.5$ to 6.5 ), (b) Adjusted at around 4 by $\mathrm{HCl}$ and (c) Adjusted at around 12 by $\mathrm{NaOH}$. The crevice specimens were placed in the glass vessel, and the simulated $\mathrm{NaCl}$ completion fluid was poured into the vessel and heated up to test temperature if neces-
Table 1. Chemical composition (mass $\%$ ) of materials.

\begin{tabular}{|c|c|c|c|c|c|}
\hline Steel & $\mathrm{C}$ & $\mathrm{Si}$ & $\mathrm{Mn}$ & $\mathrm{Cr}$ & $\mathrm{Mo}$ \\
\hline \multirow{2}{*}{$1 \% \mathrm{Cr}$} & 0.26 & 0.25 & 0.84 & 1.12 & 0.32 \\
\cline { 2 - 6 } & 0.26 & 0.26 & 0.80 & 0.96 & 0.09 \\
\hline \multirow{2}{*}{$3 \mathrm{Cr}$} & 0.17 & 0.24 & 0.40 & 3.22 & 0.01 \\
\hline
\end{tabular}

Table 2. Completion fluid.

\begin{tabular}{|l|l|}
\hline & Chemical \\
\hline Brine & $1.03 \mathrm{SG} \mathrm{NaCl}$ \\
\hline Biocide & $0.5 \mathrm{ml} / / \mathrm{Glutaraldehyde}$ \\
\hline Oxygen scavenger & $0.5 \mathrm{ml} / / \mathrm{NaHSO}_{3}$ \\
\hline Sodium hydroxide & Adjusted at $\mathrm{pH}$ more than 11 \\
\hline
\end{tabular}

Table 3. Test condtions of simulated completion fluid environments.

\begin{tabular}{|c|c|c|c|c|}
\hline Test solution & Deaeration & $\begin{array}{c}\mathrm{pH} \\
\text { (aiming value) }\end{array}$ & $\begin{array}{c}\text { Temperature } \\
\left({ }^{\circ} \mathrm{C}\right)\end{array}$ & $\begin{array}{c}\text { Exposure } \\
\text { duration } \\
\text { (hr.) }\end{array}$ \\
\hline \multirow{6}{*}{$1.03 \mathrm{SG} \mathrm{NaCl}$} & No & $\begin{array}{c}4 \\
\text { (adjusted by } \mathrm{HCl} \text { ) }\end{array}$ & $25,50,70,90$ & 120 \\
\hline & No & $\begin{array}{l}\text { No control } \\
\text { (5.5 to } 6.5)\end{array}$ & $25,50,70,90$ & 120 \\
\hline & No & $\begin{array}{c}12 \\
\text { (adjusted by } \mathrm{NaOH} \text { ) }\end{array}$ & $25,50,70,90$ & 120 \\
\hline & $\begin{array}{c}\text { Yes } \\
\text { (purging with } \mathrm{N}_{2} \text { gas) }\end{array}$ & $\begin{array}{l}\text { No control } \\
(5.5 \text { to } 6.5) \\
\end{array}$ & 90 & 720 \\
\hline & $\begin{array}{c}\text { Yes } \\
\text { (purging with } \mathrm{N}_{2} \text { gas) }\end{array}$ & $\begin{array}{c}12 \\
\text { (adjusted by } \mathrm{NaOH} \text { ) }\end{array}$ & 90 & 720 \\
\hline & 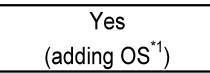 & $\begin{array}{c}12 \\
\text { (adjusted by } \mathrm{NaOH} \text { ) }\end{array}$ & 90 & 120 \\
\hline
\end{tabular}

*1: OS(oxygen scavenger) $=0.5 \mathrm{ml} / \mathrm{l} \mathrm{NaHSO}_{3}$

sary. The specific solution volume (solution volume divided by specimen surface area) was more than $20 \mathrm{~mL} / \mathrm{cm}^{2}$.

After testing, specimens were taken out and corrosion products were removed from crevice test specimens. Test specimens were immersed in $10 \mathrm{wt} \%$ ammonium citrate dibasic solution. Then, corrosion products were removed by a nonwoven abrasive sheet. After removing corrosion products, corrosion rate was calculated and localized corrosion was evaluated by visual observation. In this paper, all corrosion rates were calculated by dividing weight loss by the all surface area of specimen and test duration.

The corrosion products were analyzed using X-ray diffraction for the black deposit.

In order to measure the $\mathrm{pH}$ under the black deposit, the corrosion products were partially scraped using knife blade to expose their cross section. $\mathrm{pH}$ at the corner of the cross section and the revealed substrate steel was measured using micro $\mathrm{pH}$ probe as the $\mathrm{pH}$ at the interface between corrosion products and steel. Coupon test specimens were also immersed in the simulated $\mathrm{NaCl}$ completion fluid with $\mathrm{DO}$ concentration of $25 \mathrm{ppb}$ to investigate corrosion products and secondary ion mass spectroscopy (SIMS) analysis was carried out on tested coupon specimen without removing corrosion products for studying $\mathrm{Cr}$ enrichment in the corrosion products.

\subsubsection{Corrosion Tests in Simulated Oil Production Envi- ronment}

As shown in Table 4, an immersion test was carried out using an autoclave in a simulated oil production environment of $0.3 \mathrm{MPa} \mathrm{CO}_{2}$ at $90^{\circ} \mathrm{C}$. The test solution had the same chemicals as the production fluid in the well of oil 
Table 4. Test condition of a simulated oil production environment.

\begin{tabular}{|c|c|c|c|c|}
\hline Test solution & $\mathrm{T}\left({ }^{\circ} \mathrm{C}\right)$ & $\begin{array}{c}\text { Gas/Partial } \\
\text { pressure }(\mathrm{MPa})\end{array}$ & \begin{tabular}{|c|} 
Calculated \\
$\mathrm{pH}$
\end{tabular} & \begin{tabular}{|c}
$\begin{array}{c}\text { Duration } \\
\text { (hr.) }\end{array}$ \\
\end{tabular} \\
\hline $\begin{array}{l}\mathrm{Na}^{+}=8640 \mathrm{mg} / \mathrm{l} \\
\mathrm{K}^{+}=190 \mathrm{mg} / \mathrm{l} \\
\mathrm{Ca}^{2+}=300 \mathrm{mg} / \mathrm{l} \\
\mathrm{Mg}^{2+}=70 \mathrm{mg} / \mathrm{l} \\
\mathrm{Ba}^{2+}=60 \mathrm{mg} / \mathrm{l} \\
\mathrm{Sr}^{2+}=50 \mathrm{mg} / \mathrm{l} \\
\mathrm{Cl}^{-}=14300 \mathrm{mg} / \mathrm{l} \\
\mathrm{HCO}_{3}^{-}=1100 \mathrm{mg} / \mathrm{l} \\
\mathrm{CH}_{3} \mathrm{COOH}=397 \mathrm{mg} / \mathrm{l}\end{array}$ & 90 & $\mathrm{CO}_{2} / 0.3$ & 5.7 & 720 \\
\hline
\end{tabular}

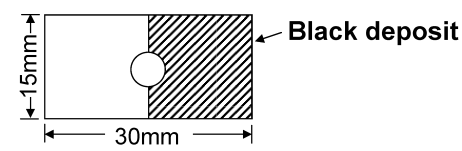

(a)Smaller specimen

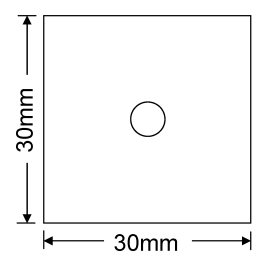

(b)Larger specimen

Fig. 1. Crevice test specimens used in this study. (a) Smaller specimen, (b) larger specimen.

leakage. The calculated $\mathrm{pH}$ of the test solution is 5.7 at the test condition. In order to investigate the corrosion behavior under black deposit on $1 \% \mathrm{Cr}$ and $3 \% \mathrm{Cr}$ steels in the oil production environment, crevice specimens with a black deposit between the smaller and the larger test coupons were used as shown in Fig. 1. Coupon test specimens were also used to examine the corrosion behavior without black deposit. The black deposit used in this study was made by a $5 \mathrm{~d}$-immersion of $3 \% \mathrm{Cr}$ steel in the aerated $1.03 \mathrm{SG} \mathrm{NaCl}$ solution of $\mathrm{pH} 12$ at $90^{\circ} \mathrm{C}$. The test solution was fully deaerated by purging with $\mathrm{N}_{2}$ gas for $20 \mathrm{~h}$ in order to make DO concentration in the test solution be equal to or less than $10 \mathrm{ppb}$. Then, the deaereated test solution was transferred to the autoclave under vacuum.

Corrosion rate and localized corrosion were evaluated by the same manner as corrosion tests in the simulated $\mathrm{NaCl}$ completion fluid environments.

\subsubsection{Electrochemical Test}

The corrosion potentials of $1 \% \mathrm{Cr}$ and $3 \% \mathrm{Cr}$ steels were measured for $1 \mathrm{~h}$ in aerated and deaerated $1.03 \mathrm{SG}$ $\mathrm{NaCl}$ solutions with $\mathrm{pH}$ of 12.0 at $90^{\circ} \mathrm{C}$.

As explained later, black deposit developed on $1 \% \mathrm{Cr}$ and $3 \% \mathrm{Cr}$ steels in the aerated alkaline $\mathrm{NaCl}$ solution with $\mathrm{pH}$ of 10 to 12 . The $\mathrm{pH}$ was 3.6 to 5.4 at the interface between metal surface and black deposit. Therefore, in the aerated $\mathrm{NaCl}$ solutions with different $\mathrm{pH}$ of 12.0 and 4.6 that was intermediate value of $\mathrm{pH}$ at the interface between metal surface and black deposit, the anodic polarization curves of $1 \% \mathrm{Cr}$ and $3 \% \mathrm{Cr}$ steels were measured at $90^{\circ} \mathrm{C}$ after $1 \mathrm{~h}$ exposure in the solutions with sweep speed of $20 \mathrm{mV} / \mathrm{min}$ to examine each corrosion behavior under alkaline $\mathrm{NaCl}$ completion fluid and under black deposit envi-

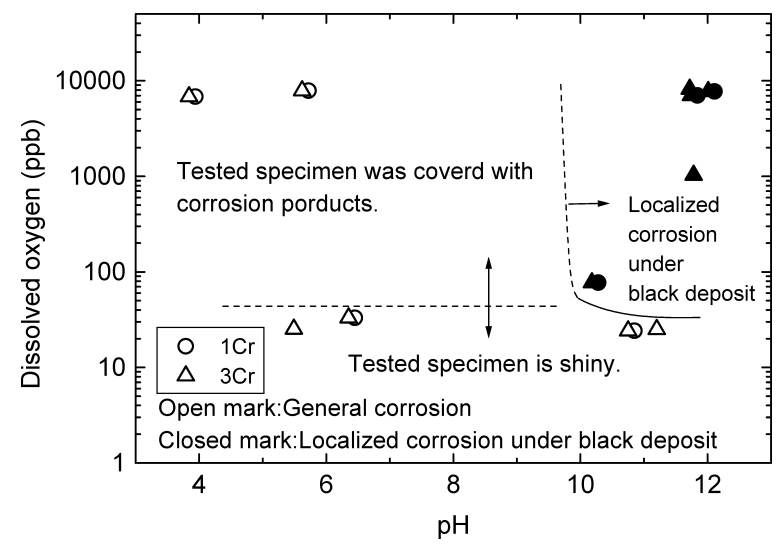

Fig. 2. The relationship among localized corrosion under black deposit, dissolved oxygen and $\mathrm{pH}$ in $\mathrm{NaCl}$ solution at $90^{\circ} \mathrm{C}$.

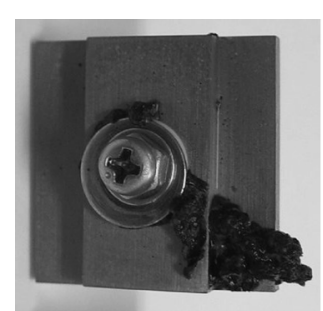

(a)before descaling
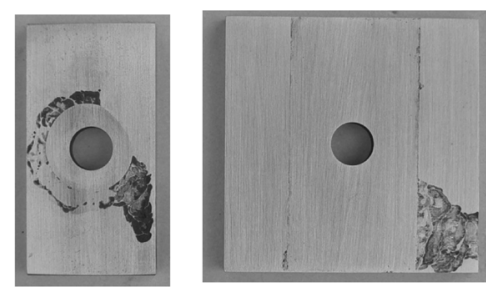

(b)after descaling

$10 \mathrm{~mm}$
Fig. 3. The appearance of tested specimen (aerated 1.03 SG $\mathrm{NaCl}, \mathrm{pH}=12.0,90^{\circ} \mathrm{C}, 5 \mathrm{~d}$ ). (a) Before descaling, (b) after descaling.

ronments.

$\mathrm{An} \mathrm{Ag} / \mathrm{AgCl} /$ saturated $\mathrm{KCl}$ electrode was used as the reference electrode, and platinum was used as the counter electrode.

\section{Results and Discussion}

\subsection{Corrosion Tests in Simulated $\mathrm{NaCl}$ Completion Fluid Environments}

\subsubsection{The Effect of DO Concentration and $\mathrm{pH}$}

Figure 2 demonstrates the form of corrosion under black deposit in $\mathrm{NaCl}$ solutions for various $\mathrm{pH}$ and $\mathrm{DO}$ concentration at $90^{\circ} \mathrm{C}$. DO concentration and $\mathrm{pH}$ were measured at room temperature. In the $\mathrm{NaCl}$ solutions with $\mathrm{pH}$ more than 10 and DO concentration equal to or more than $77 \mathrm{ppb}$, black deposit developed locally on $1 \% \mathrm{Cr}$ and $3 \% \mathrm{Cr}$ steels. Namely, the local black deposit develops in the alkaline environment with high DO concentration. Figure 3 shows the appearance of tested crevice specimens of $3 \% \mathrm{Cr}$ steel. The black deposit was not observed at the crevice portion but on the larger coupon around the smaller coupon fasten to the larger coupon. The black deposit was also observed on the smaller coupon around the PTFE (polytetrafluoroethylene) washer. Moreover, it was also observed that localized corrosion occurred under the black deposit. However, the surface without the black deposit remained metallic luster. When DO concentration was 33 ppb or less, specimens remained metallic luster and did not suffer from any localized corrosion regardless of $\mathrm{pH}$ in the range between 5 and 12 . When $\mathrm{pH}$ was less than 7 , all specimen surfaces were covered with corrosion products and specimen suf- 


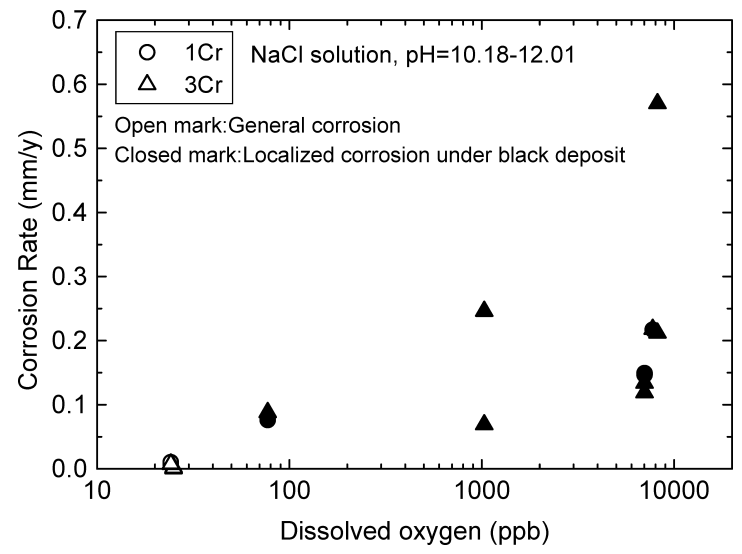

Fig. 4. The relationship between corrosion rate and dissolved oxygen in $1.03 \mathrm{SG} \mathrm{NaCl}$ solution at $90^{\circ} \mathrm{C}$.

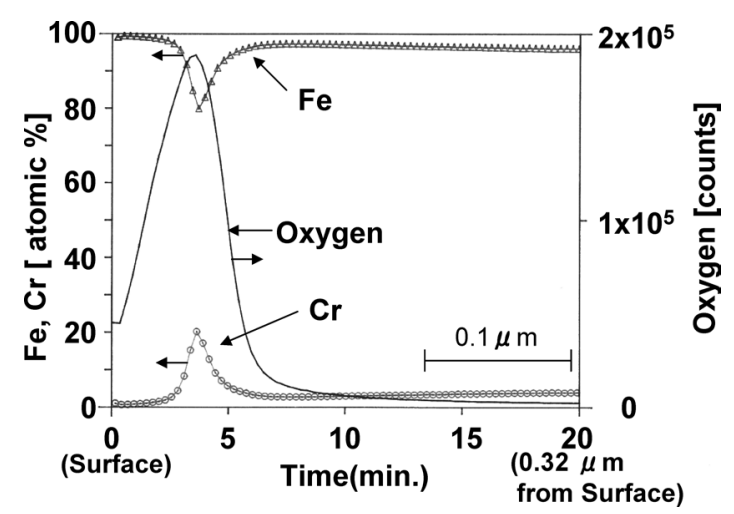

Fig. 5. SIMS analysis results on film formed on $3 \% \mathrm{Cr}$ steel in $1.03 \mathrm{SG} \mathrm{NaCl}$ with $\mathrm{pH}$ of 11.2 at $90^{\circ} \mathrm{C}(\mathrm{DO}=25 \mathrm{ppb})$.

fered general corrosion with corrosion rate from approximately 0.1 to $0.25 \mathrm{~mm} /$ year in the aerated test solutions. The corrosion rates of general corrosion did not depend on $\mathrm{pH}$.

Figure 4 describes the corrosion rate in $\mathrm{NaCl}$ solutions with $\mathrm{pH}$ above 10 as a function of DO concentration at $90^{\circ} \mathrm{C}$. Corrosion rates of $1 \% \mathrm{Cr}$ and $3 \% \mathrm{Cr}$ steels increased with increasing DO concentration. This increase in corrosion rate is due to the progress in the localized corrosion under the black deposit, because corrosion was observed only under black deposit. Figure 5 shows the SIMS depth profile of the surface film formed on the coupon specimen of $3 \% \mathrm{Cr}$ steel, which exhibits the metallic luster, in deaerated $\mathrm{NaCl}$ solution with $25 \mathrm{ppb} \mathrm{DO}$ at $90^{\circ} \mathrm{C} . \mathrm{Cr}, \mathrm{Fe}$ and $\mathrm{O}$ were detected from the surface until approximately $0.15 \mu \mathrm{m}$ in depth $(9.4 \mathrm{~min})$. At the peak of $\mathrm{Cr}$ located at approximately $0.06 \mu \mathrm{m}(4 \mathrm{~min})$, the $\mathrm{Cr}$ and $\mathrm{Fe}$ contents in metals included in film were approximately 20 and 80 at $\%$, respectively. From these results, the reason of the remaining metallic luster on $1 \% \mathrm{Cr}$ and $3 \% \mathrm{Cr}$ steel in $\mathrm{NaCl}$ solutions with low DO concentration (33 ppb or less) is considered to be the formation of $\mathrm{Cr}$ enriched iron oxide film which acts as protective film. Figure $\mathbf{6}$ shows X-ray diffraction pattern of the black deposit which developed on $3 \% \mathrm{Cr}$ steel in $\mathrm{NaCl}$ solution at $90^{\circ} \mathrm{C}$. Strong and weak peaks that were identified to be $\mathrm{Fe}_{3} \mathrm{O}_{4}$ and $\beta$-FeOOH, respectively, were observed. The $\mathrm{pH}$ under the black deposit developed on $3 \%$ $\mathrm{Cr}$ and $1 \% \mathrm{Cr}$ steels in $\mathrm{NaCl}$ solution at $90^{\circ} \mathrm{C}$ was from 3.6 to 5.4 and lower than that in bulk $\mathrm{NaCl}$ solution as shown in

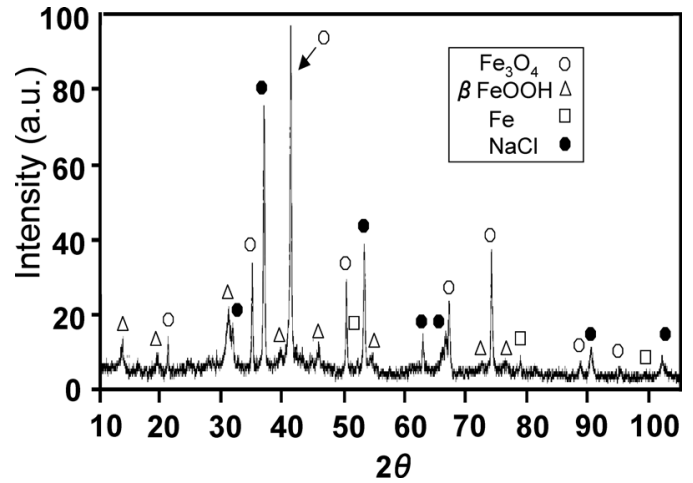

Fig. 6. X-ray diffraction analysis result of black deposit on 3\% Cr steel (1.03 SG NaCl, $\mathrm{pH}=11.7,90^{\circ} \mathrm{C}, 5 \mathrm{~d}$ ).

Table 5. $\mathrm{pH}$ measurement results on black deposit formed on steel at $90^{\circ} \mathrm{C}$.

\begin{tabular}{|c|c|c|c|c|}
\hline \multirow{2}{*}{ Steel } & \multirow{2}{*}{$\begin{array}{c}\mathrm{pH} \text { under black } \\
\text { deposit }\end{array}$} & \multirow{2}{*}{$\begin{array}{c}\mathrm{pH} \text { in bulk } \\
\text { solution }\end{array}$} & \multicolumn{2}{|l|}{ Solution } \\
\hline & & & Chemical & $\mathrm{DO}(\mathrm{ppb})$ \\
\hline $1 \% \mathrm{Cr}$ & 3.6 to 4.5 & \multirow{2}{*}{10.2} & \multirow{2}{*}{ 1.03SG NaCl+NaOH } & \multirow{2}{*}{77} \\
\hline $3 \% \mathrm{Cr}$ & 4.5 to 5.4 & & & \\
\hline $1 \% \mathrm{Cr}$ & 4.9 & \multirow{2}{*}{12.0} & \multirow{2}{*}{ 1.03SG NaCl+NaOH } & \multirow{2}{*}{7740} \\
\hline $3 \% \mathrm{Cr}$ & 5.2 & & & \\
\hline
\end{tabular}

Table 5. This lowering of $\mathrm{pH}$ is considered to be an increment in $\mathrm{H}^{+}$ion due to $\mathrm{Fe}_{3} \mathrm{O}_{4}$ and $\mathrm{HeFO}_{2}^{-}$formation reactions, as discussed later.

\subsubsection{The Effect of Temperature}

The condition for formation of the black deposit was examined in aerated $\mathrm{NaCl}$ solution by varying temperature and $\mathrm{pH}$. The results were shown in Fig. 7. When $\mathrm{pH}$ was approximately 12 , the black deposit was observed on $1 \%$ $\mathrm{Cr}$ and $3 \% \mathrm{Cr}$ steels at temperatures between 25 and $90^{\circ} \mathrm{C}$. However, the black deposit was not observed at $\mathrm{pH}$ of 4 and 6. Hence, the $\mathrm{Cr}$ enriched oxide film formed on $1 \% \mathrm{Cr}$ and $3 \% \mathrm{Cr}$ steels is considered to become unstable locally in aerated alkaline completion fluid at temperatures above $25^{\circ} \mathrm{C}$. The average corrosion rates of crevice specimens of $1 \% \mathrm{Cr}$ and $3 \% \mathrm{Cr}$ steels, which are obtained by weight loss after immersion test, in $\mathrm{NaCl}$ solutions with $\mathrm{pH}$ of approximately 4 and 12 are shown in Figs. 8(a) and 8(b) as a function of temperature. The average corrosion rate in $\mathrm{NaCl}$ solution with $\mathrm{pH}$ of approximately 12 did not depend on temperature at between 25 and $90^{\circ} \mathrm{C}$.

Figure 8 also shows that corrosion rate in $\mathrm{NaCl}$ solution with $\mathrm{pH}$ of approximately 4 was almost same as that in $\mathrm{NaCl}$ solution with $\mathrm{pH}$ of approximately 12 , except for data of $1 \% \mathrm{Cr}$ steel at $25^{\circ} \mathrm{C}$. However, corrosion morphology was different with $\mathrm{pH}$. The corrosion morphology was general corrosion at $\mathrm{pH}$ of approximately 4 and localized corrosion under black deposit at pH of approximately 12 .

\subsection{Corrosion Tests in Simulated Oil Production Envi- ronment}

The results of immersion test in the simulated oil production environment are shown in Table 6. All coupon specimens, on which the black deposit was not put before testing, did not suffer from localized corrosion but general corrosion, and no black deposit developed on the specimens. The general corrosion was attributed to $\mathrm{CO}_{2}$ corrosion. The corrosion rate was from $0.8 \mathrm{~mm} /$ year to $1.6 \mathrm{~mm} /$ year and 


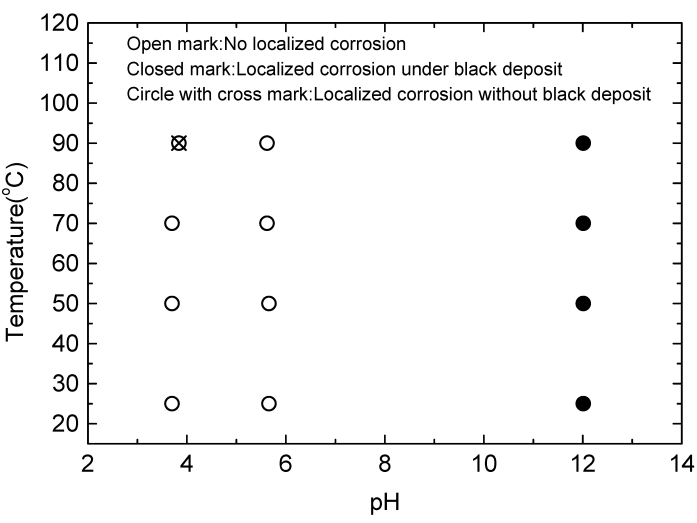

(a) $1 \% \mathrm{Cr}$ steel

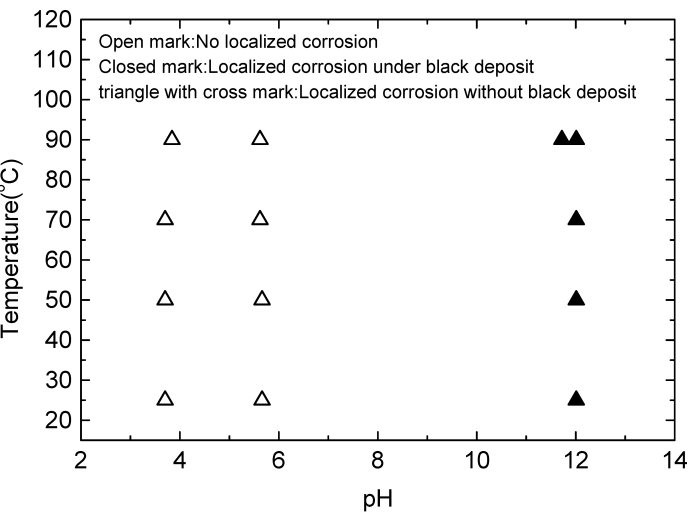

(b) $3 \% \mathrm{Cr}$ steel

Fig. 7. The relationship among localized corrosion under black deposit, temperature and $\mathrm{pH}$ in aerated $1.03 \mathrm{SG} \mathrm{NaCl}$ solution. (a) $1 \% \mathrm{Cr}$ steel, (b) $3 \% \mathrm{Cr}$ steel.

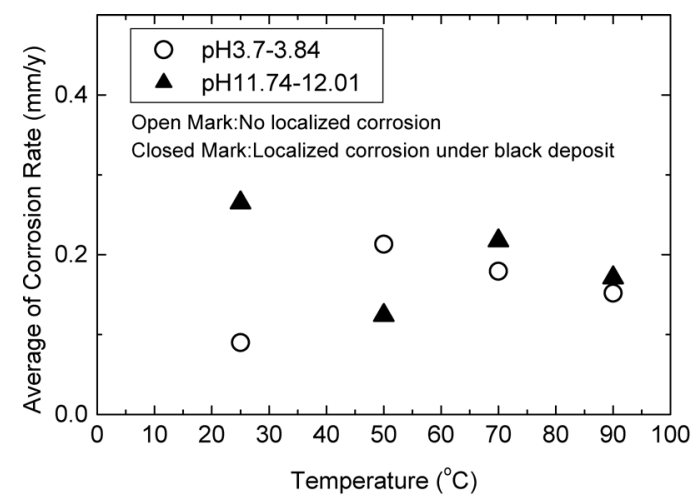

(a) $1 \% \mathrm{Cr}$

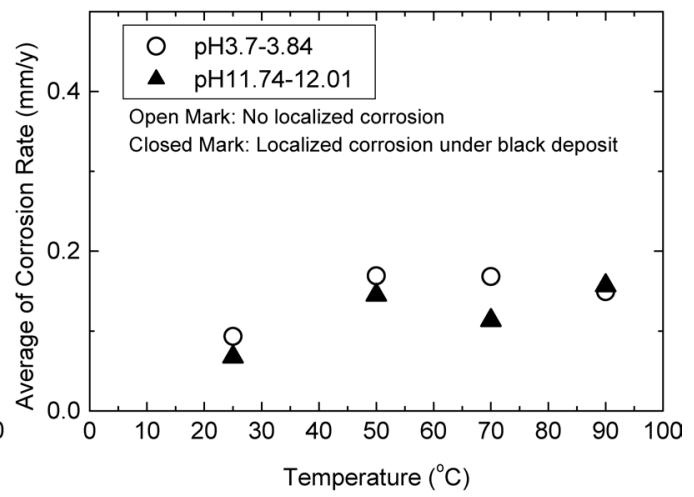

(b) $3 \% \mathrm{Cr}$

Fig. 8. The relationship between average value of corrosion rate and temperature in aerated $1.03 \mathrm{SG} \mathrm{NaCl}$ solutions (pH=11.7-12.0). (a) $1 \% \mathrm{Cr}$, (b) $3 \% \mathrm{Cr}$.

Table 6. Test results in a simulated oil production environment.

\begin{tabular}{|c|c|c|c|c|c|}
\hline \multirow{3}{*}{ Steel } & \multicolumn{3}{|c|}{ Crevice with black deposit } & \multicolumn{2}{|c|}{ Coupon w/o black deposit } \\
\hline & \multicolumn{2}{|c|}{ Corrosion rate $(\mathrm{mm} / \mathrm{y}$} & \multirow{2}{*}{$\begin{array}{c}\mathrm{LC}^{* 3} \text { under } \\
\mathrm{BD}^{* 4}\end{array}$} & \multirow{2}{*}{$\begin{array}{c}\text { Corrosion rate } \\
(\mathrm{mm} / \mathrm{y})\end{array}$} & \multirow{2}{*}{$\begin{array}{c}\text { LC under } \\
\text { BD }\end{array}$} \\
\hline & $\mathrm{L}^{* 1}$ & $S^{* 1}$ & & & \\
\hline \multirow{2}{*}{$1 \% \mathrm{Cr}$} & 1.547 & 1.025 & Yes & 1.625 & No \\
\hline & 1.524 & 0.990 & Yes & - & - \\
\hline \multirow{2}{*}{$3 \% \mathrm{Cr}$} & 0.837 & 0.584 & Yes & 0.838 & No \\
\hline & 0.818 & 0.575 & Yes & - & - \\
\hline
\end{tabular}

*1: L= Large specimen $(30 \mathrm{~mm} \mathrm{~W} \times 30 \mathrm{~mm} \mathrm{~L} \times 3 \mathrm{~mm} \mathrm{t})$

*2: $S=$ Small specimen $(15 \mathrm{~mm} \mathrm{~W} \times 30 \mathrm{~mm} \mathrm{~L} \times 3 \mathrm{~mm} \mathrm{t})$

*3: LC=localized corrosion, *4: BD= black deposit

was higher than that in the simulated alkaline $\mathrm{NaCl}$ completion fluid environments.

On the other hand, all the crevice specimens with the black deposit being loaded before testing, the slight corrosion proceeded under the black deposit as shown in Fig. 9. As described above, the black deposit was identified to be mainly $\mathrm{Fe}_{3} \mathrm{O}_{4}$. Many authors reported that in a reduction atmosphere with low oxygen concentration, anodic reaction on carbon steel will be accelerated due to cathodic reduction of $\mathrm{Fe}_{3} \mathrm{O}_{4}$ on the steel. ${ }^{6-9)}$ The corrosion progress under the black deposit observed in this corrosion test might be due to reduction of $\mathrm{Fe}_{3} \mathrm{O}_{4}$, because the $\mathrm{DO}$ concentration in this test was very low (10 ppb or less).

The reason of the oil leakage in the filed occurred 6 months after the start of production is considered to be the continuous active dissolution of the steel under the black deposit which is maintained by the $\mathrm{CO}_{2}$ corrosion and ca- thodic reduction of $\mathrm{Fe}_{3} \mathrm{O}_{4}$. Therefore it is important to keep the $\mathrm{DO}$ concentration in alkaline $\mathrm{NaCl}$ completion fluids low below $33 \mathrm{ppb}$ to prevent developing of black deposit that could accelerate the localized corrosion in oil production environments.

\subsection{Electrochemical Test}

Table 7 shows the corrosion potentials of tested materials in the $1.03 \mathrm{SG} \mathrm{NaCl}$ solution with $\mathrm{pH}$ of 12 . The corrosion potential of each material in the aerated solution tends to be more noble than that in the deaerated solution. Figures 10(a) and 10(b) show the anodic polarization curves in aerated $\mathrm{NaCl}$ solutions at $90^{\circ} \mathrm{C}$ with $\mathrm{pH}$ of 12.0 and 4.6 , respectively. In the solution with $\mathrm{pH}$ of 12.0 , the current density of $3 \% \mathrm{Cr}$ and $1 \% \mathrm{Cr}$ steels was stable in the potential range between -520 and $-460 \mathrm{mV}$ (SSE), and between -550 and $-500 \mathrm{mV}$ (SSE), respectively. In these potential ranges, $\mathrm{Cr}$ enriched iron oxide film would be formed on $3 \%$ $\mathrm{Cr}$ and $1 \% \mathrm{Cr}$ steels. Above these potentials, current density increased as potential became noble and the black deposit was observed clearly on each material above approximately $-400 \mathrm{mV}$ (SSE). Therefore, black deposit could develop on the $3 \% \mathrm{Cr}$ and $1 \% \mathrm{Cr}$ steels where $\mathrm{Cr}$ enriched iron oxide film is broken for some reason. In the solution with $\mathrm{pH}$ of 4.6 which is simulated test solution under the black deposit, the current density of $3 \% \mathrm{Cr}$ and $1 \% \mathrm{Cr}$ steels monotonously increased as potential became noble. This means that $\mathrm{Cr}$ enriched iron oxide film would not be 


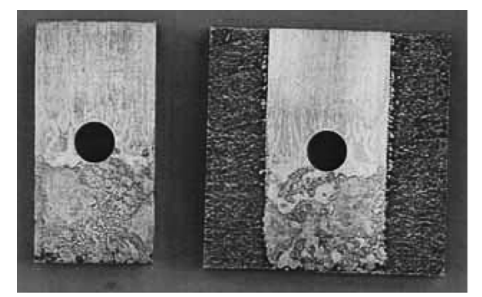

(a) $1 \% \mathrm{Cr} \quad 10 \mathrm{~mm}$

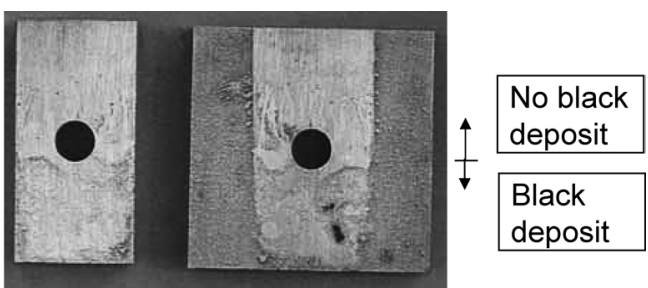

(b) $3 \% \mathrm{Cr} \quad 10 \mathrm{~mm}$

Fig. 9. The appearance of tested specimen with black deposit (after descaling) Upper half surface: no black deposit, Lower half surface: black deposit was put. (a) $1 \% \mathrm{Cr}$, (b) $3 \% \mathrm{Cr}$.

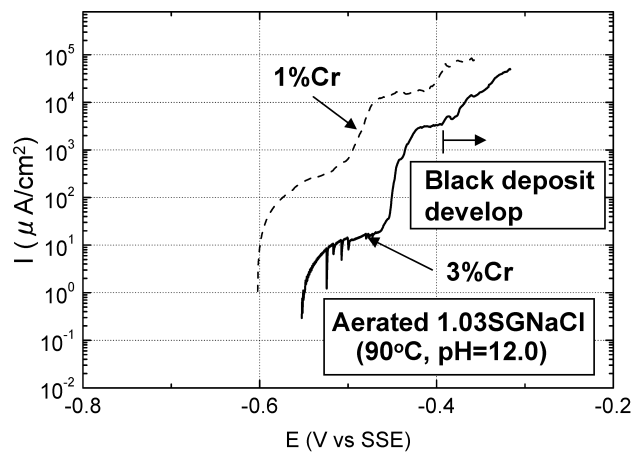

(a) $\mathrm{pH}=12.0$

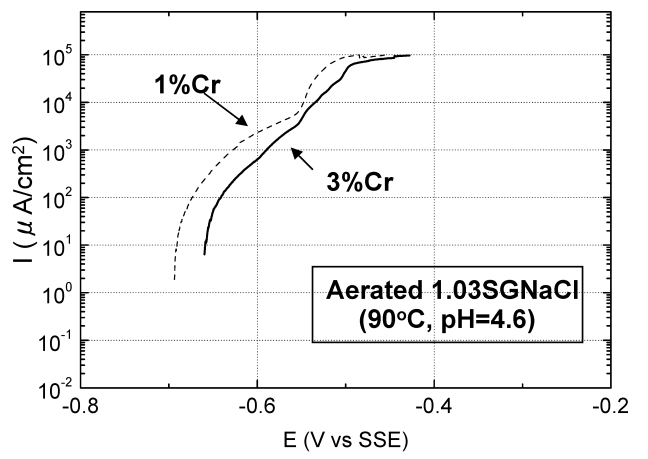

(b) $\mathrm{pH}=4.6$

Fig. 10. Anodic polarization curve in aerated $1.03 \mathrm{SG} \mathrm{NaCl}$ solution at $90^{\circ} \mathrm{C}$. (a) $\mathrm{pH}=12.0$, (b) $\mathrm{pH}=4.6$.

Table 7. Corrosion potential in $1.03 \mathrm{SG} \mathrm{NaCl}$ solution at $90^{\circ} \mathrm{C}$.

\begin{tabular}{|c|c|c|}
\hline \multirow{2}{*}{$\begin{array}{c}\text { Water } \\
\text { property }\end{array}$} & \multicolumn{2}{|c|}{ Corrosion potential $(\mathrm{mV})$} \\
\cline { 2 - 3 } $\mathrm{pH}=12.0$, & $3 \% \mathrm{Cr}$ & $1 \% \mathrm{Cr}$ \\
$\begin{array}{c}\text { Aerated } \\
\mathrm{pH}=12.0,\end{array}$ & $-552\left(\mathrm{SSE}^{* 1}\right)$ & $-682(\mathrm{SSE})$ \\
\hline $\begin{array}{c}\text { Deaerated } \\
\text { *1: SSE=saturated silver silver chloride electrode }\end{array}$ & $-575(\mathrm{SSE})$ & $-769(\mathrm{SSE})$ \\
\hline
\end{tabular}

formed and corrosion progresses in acidity solution such as the solution under the black deposit.

\subsection{Corrosion Mechanism under the Black Deposit}

This study revealed that the localized black deposit would develop on $1 \% \mathrm{Cr}$ and $3 \% \mathrm{Cr}$ steels in alkaline $\mathrm{NaCl}$ completion fluid with high DO concentration. On the other hand, the black deposit did not develop in the oil production environment in which DO concentration is low and $\mathrm{H}^{+}$ion concentration is slightly lower than neutral. Under the black deposit, localized corrosion was accelerated in both $\mathrm{NaCl}$ completion fluid and oil production environments. Since the corrosion behaviors of $1 \% \mathrm{Cr}$ and $3 \% \mathrm{Cr}$ steels were almost same, the corrosion acceleration process under the black deposit on $3 \% \mathrm{Cr}$ steel is described in the following:

- 1st Step: Black Deposit Formation in Alkaline $\mathrm{NaCl}$ Completion Fluid Environment

In Fig. 11, the potential- $\mathrm{pH}$ diagram of $\mathrm{Cr}-\mathrm{H}_{2} \mathrm{O}$ system (red dotted line) at $100^{\circ} \mathrm{C}$ is superimposed on that of $\mathrm{Fe}-$ $\mathrm{H}_{2} \mathrm{O}$ system (solid line). In this figure, ion species concentration is $10^{-3} \mathrm{~mol} / \mathrm{L}$. A closed circle mark indicates corrosion potential measured in the electrochemical test of $3 \%$ $\mathrm{Cr}$ steels in the aerated $\mathrm{NaCl}$ solution with $\mathrm{pH}$ of 12.0 at $90^{\circ} \mathrm{C}$. Since the corrosion potential was in the stable region of $\mathrm{Cr}_{2} \mathrm{O}_{3}$, and $\mathrm{Fe}_{2} \mathrm{O}_{3}$ and $\mathrm{Cr}$, $\mathrm{Fe}$ and $\mathrm{O}$ were confirmed by

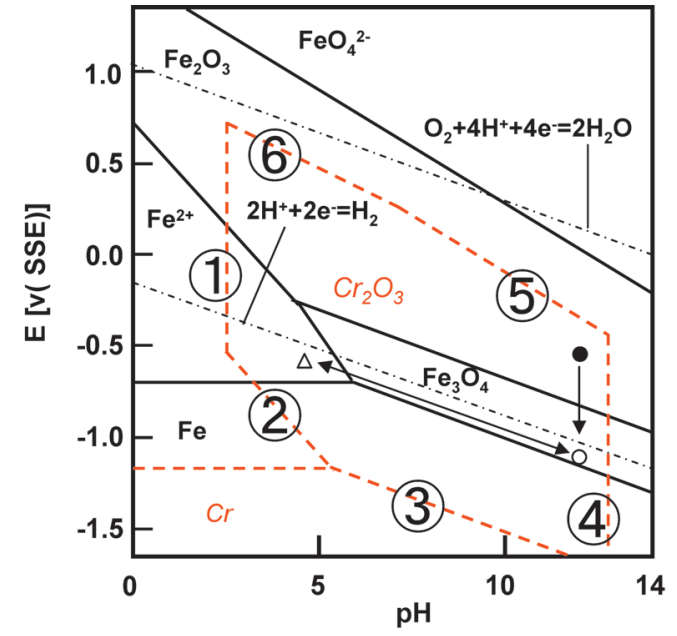

(1): $2 \mathrm{CrOH}^{2+}+\mathrm{H}_{2} \mathrm{O}=\mathrm{Cr}_{2} \mathrm{O}_{3}+4 \mathrm{H}^{+}$, (2) $: 2 \mathrm{Cr}^{2+}+3 \mathrm{H}_{2} \mathrm{O}=\mathrm{Cr}_{2} \mathrm{O}_{3}+6 \mathrm{H}^{+}+2 \mathrm{e}^{-}$, (3) $: 2 \mathrm{Cr}+3 \mathrm{H}_{2} \mathrm{O}=\mathrm{Cr}_{2} \mathrm{O}_{3}+6 \mathrm{H}^{+}+6 \mathrm{e}^{-}$, (4): $2 \mathrm{CrO}_{2}^{-}+2 \mathrm{H}^{+}=\mathrm{Cr}_{2} \mathrm{O}_{3}+\mathrm{H}_{2} \mathrm{O}$, (5): $\mathrm{Cr}_{2} \mathrm{O}_{3}+5 \mathrm{H}_{2} \mathrm{O}=2 \mathrm{CrO}_{4}^{2-}+10 \mathrm{H}^{+}+6 \mathrm{e}^{-},(6): \mathrm{Cr}_{2} \mathrm{O}_{3}+5 \mathrm{H}_{2} \mathrm{O}=2 \mathrm{HCrO}_{4}^{-}+8 \mathrm{H}^{+}+6 \mathrm{e}^{-}$

Fig. 11. Potential- $\mathrm{pH}$ diagram of $\mathrm{Fe}-\mathrm{H}_{2} \mathrm{O}$ system at $100^{\circ} \mathrm{C}$. Corrosion potential of $3 \% \mathrm{Cr}$ in aerated $\mathrm{NaCl}$ with $\mathrm{pH}$ of $12, \bigcirc$ : expected point of black deposit initiation, $\triangle$ : expected point under black deposit condition, ion species $=10^{-3} \mathrm{~mol} / \mathrm{L}$.

SIMS analysis, $\mathrm{Cr}$ enriched iron oxide film would form at the corrosion potential of $3 \% \mathrm{Cr}$ steel in the alkaline $\mathrm{NaCl}$ completion fluid environment. The black deposit of $\mathrm{Fe}_{3} \mathrm{O}_{4}$ is considered to develop where $\mathrm{Cr}$ enriched iron oxide film is broken. Since the corrosion potential is considered to be a mixed electrode potential between cathodic reaction of $\mathrm{O}_{2}$ consumption reaction, and anodic reactions such as $\mathrm{Fe}_{3} \mathrm{O}_{4}$ formation reaction and $\mathrm{Cr}$ enriched iron oxide film formation reaction, the potential at the surface of $3 \% \mathrm{Cr}$ steel could be less noble than the corrosion potential. In addition, the black deposit formed in immersion test was not indenti- 


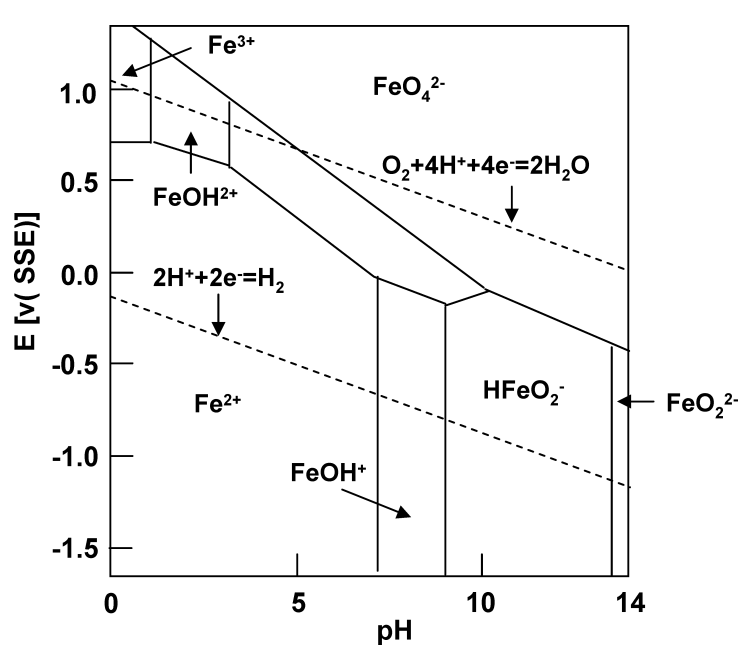

Fig. 12. Potential-pH diagram of $\mathrm{Fe}-\mathrm{H}_{2} \mathrm{O}$ system at $100^{\circ} \mathrm{C}$ concerning stable ion species.

fied as $\mathrm{Fe}_{2} \mathrm{O}_{3}$ but $\mathrm{Fe}_{3} \mathrm{O}_{4}$ mainly by $\mathrm{X}$-ray analysis.

Therefore, at the site of oxide breakdown, potential would become less noble closely to the equilibrium potential between $\mathrm{Fe}$ and $\mathrm{Fe}_{3} \mathrm{O}_{4}$, as indicated in an open circle mark in Fig. 11. As a result, $\mathrm{Fe}_{3} \mathrm{O}_{4}$ could develop as the black deposit.

Moreover, the black deposit was observed in the $\mathrm{NaCl}$ test solutions of $\mathrm{pH}$ from 10 to 12 with $\mathrm{DO}$ concentration equal to or more than $77 \mathrm{ppb}$ and $\mathrm{HFeO}_{2}{ }^{-}$is the stable ion species in the $\mathrm{pH}$ range between 10 and 12 according to the potential-pH diagram for stable ion species concerning $\mathrm{Fe}-\mathrm{H}_{2} \mathrm{O}$ system at $100^{\circ} \mathrm{C}$, as shown in Fig. 12 .

Therefore, the corrosion reaction with $\mathrm{Fe}_{3} \mathrm{O}_{4}$ formation is described as follows:

Cathodic reaction (consumption of DO at the exposed steel surface)

$$
\mathrm{O}_{2}+2 \mathrm{H}_{2} \mathrm{O}+4 \mathrm{e}^{-} \rightarrow 4 \mathrm{OH}^{-}
$$

Anodic reaction

$$
\begin{aligned}
& \mathrm{Fe}+2 \mathrm{H}_{2} \mathrm{O} \rightarrow \mathrm{HFeO}_{2}^{-}+3 \mathrm{H}^{+}+2 \mathrm{e}^{-}, \\
& \quad \text { for } 9 \leq \mathrm{pH} \leq 13.5 \ldots \ldots \ldots \ldots \ldots \ldots \ldots \ldots \ldots \ldots
\end{aligned}
$$

If the concentration of $\mathrm{HFeO}_{2}^{-}$ion is increased, $\mathrm{Fe}_{3} \mathrm{O}_{4}$ would be formed by the reaction (3).

$$
3 \mathrm{HFeO}_{2}^{-} \rightarrow \mathrm{Fe}_{3} \mathrm{O}_{4}+\mathrm{H}_{2} \mathrm{O}+\mathrm{OH}^{-}+2 \mathrm{e}^{-}
$$

From reactions (2) and (3), $\mathrm{Fe}_{3} \mathrm{O}_{4}$ formation reaction is described as follows:

$$
3 \mathrm{Fe}+4 \mathrm{H}_{2} \mathrm{O} \rightarrow \mathrm{Fe}_{3} \mathrm{O}_{4}+8 \mathrm{H}^{+}+8 \mathrm{e}^{-}
$$

- 2nd Step: Corrosion Growth under the Black Deposit in Alkaline $\mathrm{NaCl}$ Completion Fluid Environment

The black deposit of $\mathrm{Fe}_{3} \mathrm{O}_{4}$ grows up to certain amount, then $\mathrm{H}^{+}$ion generated by reaction (4) would be accumulated under the black deposit. Consequently, $\mathrm{pH}$ of the solution could be lowered under the black deposit, as shown in Table 5. Corrosion under the black deposit could be progressed during the lowering of $\mathrm{pH}$. The lowering of $\mathrm{pH}$ is considered to continue to the stable region of $\mathrm{Fe}^{2+}$ ion as shown in open triangle mark in Fig. 11, because the measured $\mathrm{pH}$ under the black deposit was from 3.6 to 5.4.
According to the potential-pH diagram shown in Fig. 12, the stable ion species vary with $\mathrm{pH}$. Therefore, anodic reactions of $\mathrm{Fe}$ dissolution reaction during the lowering of $\mathrm{pH}$ are described as follows:

$$
\begin{aligned}
& \mathrm{Fe}+2 \mathrm{H}_{2} \mathrm{O} \rightarrow \mathrm{HFeO}_{2}^{-}+3 \mathrm{H}^{+}+2 \mathrm{e}^{-}, \\
& \text {for } 9 \leq \mathrm{pH} \leq 13.5 \text {. } \\
& \mathrm{Fe}+\mathrm{H}_{2} \mathrm{O} \rightarrow \mathrm{FeOH}^{+}+\mathrm{H}^{+}+2 \overline{\mathrm{e}}, \quad \text { for } \quad 7.3<\mathrm{pH}<9 \ldots \\
& \mathrm{Fe} \rightarrow \mathrm{Fe}^{2+}+2 \mathrm{e}^{-}, \quad \text { for } \mathrm{pH}<7.3
\end{aligned}
$$

If the concentration of $\mathrm{HFeO}_{2}^{-}, \mathrm{FeOH}^{+}$and $\mathrm{Fe}^{2+}$ ions increase, $\mathrm{Fe}_{3} \mathrm{O}_{4}$ would be formed by oxidation reaction of aqueous ions including ferrous ion such as reactions (3) and (4).

On the other hand, possible cathodic reactions are reductions of $\mathrm{DO}, \mathrm{Fe}_{3} \mathrm{O}_{4}$ and of $\mathrm{H}^{+}$ion.

$$
\mathrm{O}_{2}+2 \mathrm{H}_{2} \mathrm{O}+4 \mathrm{e}^{-} \rightarrow 4 \mathrm{OH}^{-}
$$

$$
\begin{array}{r}
\mathrm{Fe}_{3} \mathrm{O}_{4}+8 \mathrm{H}^{+}+2 \mathrm{e}^{-} \rightarrow 3 \mathrm{Fe}^{2+}+4 \mathrm{H}_{2} \mathrm{O} . \\
2 \mathrm{H}^{+}+2 \mathrm{e}^{-} \rightarrow \mathrm{H}_{2} \ldots \ldots \ldots \ldots \ldots \ldots \ldots \ldots . . .
\end{array}
$$

DO reduction (1) in this step occurs at the outside of black deposit because DO under the black deposit would be almost consumed in the step 1 .

$\mathrm{H}^{+}$reduction (8) would occur under the black deposit when $\mathrm{H}^{+}$ion increases (low $\mathrm{pH}$ ). Taking account of corrosion under the black deposit, possible anodic reactions are $\mathrm{Fe}_{3} \mathrm{O}_{4}$ formation (4) and $\mathrm{Fe}$ dissolution reaction (6). If $\mathrm{Fe}^{2+}$ ion increases by reaction (6), $\mathrm{Fe}_{3} \mathrm{O}_{4}$ reduction (7) would hardly occur.

From reactions of $\mathrm{Fe}_{3} \mathrm{O}_{4}$ formation (4) and $\mathrm{H}^{+}$reduction (8), corrosion reaction under the black deposit is described as the following reaction (9). In reactions of (9) and (6), $\mathrm{H}^{+}$ does not form under the black deposit. Therefore, after the consumption of $\mathrm{H}^{+}$under the black deposit, cathodic reaction would be only DO reduction (1) at outside the black deposit.

$$
3 \mathrm{Fe}+4 \mathrm{H}_{2} \mathrm{O} \rightarrow \mathrm{Fe}_{3} \mathrm{O}_{4}+4 \mathrm{H}_{2}
$$

- 3rd Step: Corrosion Growth under the Black Deposit in the Oil Production Environment

In this step, corrosion progressed gradually under the black deposit by the $\mathrm{CO}_{2}$ corrosion and reduction of $\mathrm{Fe}_{3} \mathrm{O}_{4}$ (7) in production fluid environment with low DO concentration.

The oil leakage occurred 6 months after the start of production on $3 \% \mathrm{Cr}$ steel is attributed to corrosion progress which started under the black deposit in the alkaline $\mathrm{NaCl}$ completion fluid and then continued in production fluid. Since the corrosion rate in the simulated oil production environment was higher than that in the simulated alkaline $\mathrm{NaCl}$ completion fluid environments, corrosion progress under the black deposit in the oil production environment would be faster than that in the alkaline $\mathrm{NaCl}$ completion fluid environments. The black deposit might accelerate the corrosion as oxidant. Since the black deposit developed on $1 \% \mathrm{Cr}$ steel in the alkaline $\mathrm{NaCl}$ solutions, same leakage could occur on $1 \% \mathrm{Cr}$ steel. Therefore, it is important to 
keep DO concentration in alkaline $\mathrm{NaCl}$ completion fluid low (33 ppb or below) for elimination of the black deposit.

\section{Conclusion}

(1) In the completion fluid of $\mathrm{NaCl}$ whose $\mathrm{pH}$ is from 5 to 12 , if the dissolved oxygen concentration is below $33 \mathrm{ppb}, \mathrm{Cr}$ enriched iron oxide film on $1 \% \mathrm{Cr}$ and $3 \% \mathrm{Cr}$ steels will be stable and act as corrosion protective film.

(2) In the alkaline $\mathrm{NaCl}$ completion fluid whose $\mathrm{pH}$ is from 10 to 12 , if the dissolved oxygen concentration is above $77 \mathrm{ppb}$, local black deposit of $\mathrm{Fe}_{3} \mathrm{O}_{4}$ develops on $1 \%$ $\mathrm{Cr}$ and $3 \%$ Cr steels.

(3) Corrosion progresses under the black deposit in both $\mathrm{NaCl}$ completion fluid and oil production environments. The corrosion progress could cause oil leakage after oil production.

(4) In order to prevent oil leakage problem on the low $\mathrm{Cr}$ tubing exposed in alkaline $\mathrm{NaCl}$ completion fluid, it is necessary to eliminate the black deposit formation in the completion fluid and it is important to control the dissolved oxygen in the completion fluid to or below $33 \mathrm{ppb}$.

\section{REFERENCES}

1) P. I. Nice, H. Takabe and M. Ueda: Proc. Int. Conf. of Corrosion 2000, NACE, Texas, (2000), paper No. 00154.

2) H. Takabe and M. Ueda: Proc. Int. Conf. of Corrosion 2001, NACE, Texas, (2001), paper No. 01066.

3) H. Takabe and M. Ueda: Proc. Int. Conf. of Corrosion 2002, NACE, Texas, (2002), paper No. 02041.

4) H. Takabe and M. Ueda: Zairyo-to-Kankyo, 56 (2007), 514.

5) P. I. Nice, A. M. Buene, H. Takabe: Proc. Int. Conf. of Corrosion 2006, NACE, Texas, (2006), paper No. 06134.

6) H. Watanabe, A. Nishikata and T. Tsuru: Proc. 46th Jpn. Conf. of Material and Environments, JSCE, Tokyo, (1999), 261.

7) A. Araoka, H. Watanabe, A. Nishikata and T. Tsuru: Proc. 2000 Fall Meeting of Electrochemical Society of Japan, (2000), 191.

8) T. Tsushima, N. Hara and K. Sugimoto: Zairyo-to-Kankyo, 52 (2003), 545.

9) Y. Kojima and S. Tsujikawa: Proc. 44th Jpn. Conf. of Material and Environments, JSCE, Tokyo, (1997), 421. 